US WURK LXX (2021), p. 1

\title{
[1528] Taking Stock of Old Frisian Studies: 1992-2021
}

\author{
Rolf H. Bremmer Jr
}

\section{Introduction}

Old Frisian is the youngest member of the group of Old Germanic languages, at least if we judge by vernacular texts preserved in manuscripts. ${ }^{1}$ However, Frisian as a language emerged much earlier, in runic inscriptions, some twenty of which have surfaced until today, dating to between 400 and 800 A.D. (Looijenga and Quak 1996; Nielsen 1996; Giliberto 1998 and 2000; Page 2001; Quak 2010; Versloot 2014a; Versloot 2016; Bleck 2016, cf. Quak 2016, Graf 2019). Also individual Frisian words have come to light interspersed in early medieval Latin texts, notably the Lex Frisionum (ca. 800) (Versloot 2015), a draft for a law that never received imperial approval (Schmidt-Wiegand 2001; Algra 2003). Because of the gap between this early Frisian and the Old Frisian as preserved in high medieval manuscripts, this early phase of the language is sometimes called Ante-Old Frisian, a term coined by Nielsen (1994; cf. Quak 2012). A conspicuous aspect of the Frisian series of runes is that some of them, viz. F, F, F, also occur in the Anglo-Saxon runic futhorc, because English and Frisian underwent similar sound-changes in the same period, viz. Gmc $a$, represented by $\mathrm{F}$, under certain conditions becomes either $\alpha$ or $o$ (irrespective of length), and hence new runes were required. Opinions differ on who invented these adapted runes, but it is generally held that the Frisians borrowed them from the

1. This is the original version of 'Bilan des études sur le vieux frison (1992-2021)', to be published in the course of 2021 in Revue germanique internationale 32 (Paris: CNSR Editions: https://journals.openedition.org/rgi/), a special issue devoted to the state-ofthe-art of Old Germanic studies. I have written this survey at the kind invitation of Daniel Petit (Professor of Indo-European Linguistics at the Ecole Normale Supérieure, Paris) and Audrey Mathys (Humboldt Stiftung, Munich). On the whole, I have refrained from incorporating into this survey publications from before 1992, for which see Bremmer (1992), which comprises a detailed analytical bibliography of virtually all publications on the various aspects of Old Frisian studies up to 1992, including reviews. In the present survey, I have focused on publications not in Dutch or Frisian, but in English and German and, occasionally, in Italian. It is perhaps significant for the neglect of attention for Old Frisian in Francophone countries that I was unable to find any publication in French from 1992 onwards.

Us Wurk 70 (2021), s. 1-28; https://doi.org/10.21827/5fb7c91ed9fba 


\section{US WURK LXX (2021), p. 2}

Anglo-Saxons. Stiles (1995: 184-188) and, independently, Parsons (1996) presented conclusive arguments for their Anglo-Saxon origin (cf. Nielsen 1995; Bammesberger 1996; Parsons 1996). Some runic inscriptions have proved quite challenging in various ways and new interpretations are offered on a regular basis (e.g., Nielsen 1993; Grønvik 1994; Bammesberger 1999; Looijenga 2003; Nedoma 2007 and 2014; Schuhmann 2014).

Place-names and personal names, too, offer a welcome insight into the earliest phases of the Frisian language (Quak 1996 and 2003). Very few place-names predate the period of the Germanic migrations (ca. 400-ca. 500 A.D.), in line with a break in the habitation along the coast after the collapse of the Roman empire (Blok 1996). Archaeological evidence has increasingly made clear over the past three decades that there was discontinuity in occupancy. It appears that a majority of the population in the coastal regions moved elsewhere, partly due to problems with the natural drainage of the salt marshes at the end of the Roman period (Nieuwhof et al. 2020: 246248). While the Frisians in Roman times dwelled in the area between the mouth of the Old Rhine in the west to the mouth of the Ems in the east, their territory appeared to have greatly expanded after the Migrations. It now encompassed the North Sea litoral from the Scheldt estuary to that of the Weser, if never more than some 25 to $40 \mathrm{kms}$ inland. According to archaeologists, the wetlands of Central Frisia were repopulated after ca. 400 A.D. mainly by immigrants from Northern Germany (Bazelmans 2002, 2009; Nieuwhof 2013), a point still under investigation. Understandably, supposing discontinuity of habitation also has repercussions on our perception of the origins of the Frisian language (e.g., Schneider 2011; Versloot 2021).

Somewhere between 600 and 800, Frisian gradually moved away from the dialect continuum on the North Sea litoral - also known as North Sea Germanic or Ingvaeonic - of which it was part. It now started to acquire the linguistic characteristics which distinguished it from its neighbouring dialects/languages: Old English, Old Saxon and Old Dutch or Old Low Franconian (Nielsen 1991, 2001; Århammar 1990; Hofstra 2003; Bremmer 2008a; de Vaan 2017).

- Some conspicuous phonological features are (Bremmer 2009: §204): monophthongization of Gmc $a u>\bar{a}$ (e.g., bām 'tree') and of Gmc $a i>\bar{a}$ or $\bar{e}$ (e.g., $r \bar{a} p$ 'rope', ben 'bone'). The latter dual development has been much discussed (cf. de Vaan 2011; Versloot 2017); fronting of Gmc $a>e$ (e.g., stef 'staff'); breaking of $e$ and $i$ before $\chi, \chi t, \chi s$ (e.g., tiuche <*tehhō- 'parcel of land', riucht < *rext- 'right', Modern West Frisian mjoks < OFris

*miuchs <*mehsa- 'dung'); labio-velar breaking of $i>i u$ [ju] (e.g., niugen 


\section{US WURK LXX (2021), p. 3}

$<*$ nigun < *newum- 'nine', siunga < *sigwan- 'to sing; loss of final - $n$ in infinitives, in endings of oblique forms of nouns and adjectives, in some numerals and in prepositions, e.g., setta 'to set' (inf.), thes alda boda (gen.) 'of the old messenger', büta 'outside' (prep.), respectively.

- Morphonological characteristics include: generalization of fronting in the singular of feminine $\bar{o}$-stem nouns (e.g., tele 'tale', fere 'journey' as opposed to OE talu, faru); generalization of the *-ina-suffix in past participles of strong verbs, esp. Classes II, IV-VII, resulting in $i$-mutation of the stem-vowel and, where applicable, palatalization of the final stem consonant (e.g., kemen 'come', bretsen 'broken'). The same suffix led to OFris epen 'open'.

- Some morphological peculiarities: Nom./acc. plural -ar in strong masculine nouns (e.g., bāmar (cf. Versloot 2014, 2017b); personal pronouns hiu 'she' and hia 'they' begin with $h$ - (with Old English) instead of $s$ - (as in Old Dutch, Old Saxon, Old High German) (cf. Stiles 2017); the use of the adverb therr 'there' as a relative particle.

- Quite a number of words are typically Frisian (or occasionally AngloFrisian). Sometimes they concern innovations, sometimes they are Ingvaeonic/North Sea Gmc relicts. Some conspicuous examples of retentions are: bōgia 'to live, dwell' (cf. OE bōgian, vs. Du wonen, G wohnen), til + dat. 'to' (OE til + dat.; ON til + gen.), kēi 'key' (vs. Du sleutel, G Schlüssel), wèt 'wet' (vs. Du nat, G nass), wērs/wārs 'springtime' (with ON vár), fule, - $a$ 'much, many' (<*fulu-) (vs. OE feala, OHG, OS filu < * felu-; cf. Bremmer 2005). Some innovations are: fēmne, famne 'girl' (not 'woman' as in OE and OS), tusk 'tooth' (generic, not 'canine tooth'), hengst 'horse' (generic, not 'stallion'; no traces of MLat paraveredus 'courier horse' [ $>\mathrm{Du}$ paard, LG peerd, G Pferd).

When vernacular texts begin to emerge in manuscripts, Old Frisian appears to be used in a geographical space bordered on the west by the Vlie and on the east by the Weser. The language had developed two major varieties, East and West, divided by the River Lauwers. Old East Frisian in turn had evolved into two major sub-dialects, Old Ems Frisian and Old Weser Frisian. The manuscripts from east of the Lauwers overall represent an earlier phase of Old Frisian than those from the west of this river, with the exception of parts of Codex Unia (Versloot 2008: 70-75). For further details, see Bremmer (2009: §§205-208).

In the course of the eighth century, Frisians settled on a number of islands in the German Bight and in parts of the opposing mainland (Heligoland, Föhr, Amrum, Sylt, Pellworm, Eiderstedt). A second wave of 


\section{US WURK LXX (2021), p. 4}

Frisians, from the Ems estuary, colonized coastal parts of Northern Germany during the eleventh century. Saxo Grammaticus (ca. 1160-ca. 1220) calls this last area Frisia minor as opposed to Frisia maior, the original homeland of the Frisians (Århammar 2001). No medieval text witnesses have survived from what is now North Frisia (G Nordfriesland), but it is important to note that both Island North Frisian and Mainland North Frisian exhibit the typically Frisian features summed up above.

The conversion to Christianity, effectively initiated by the Anglo-Saxon missionary Willibrord in 690, and more or less completed by the AngloSaxon Willehad and the Frisian Liudger around 800, brought literacy to Frisia without leaving significant traces. The year 800 marks the definitive subjection and incorporation of the Frisians by Charlemagne into his Frankish Empire. However, for several reasons book learning remained superficial: neither monasteries were founded nor episcopal sees established within the territory of the Frisians: Viking incursions and even temporary occupation during the ninth century probably frustrated a firm ecclesiastical grip on the Frisians. Also in the tenth century, Norsemen occasionally pillaged the Frisian coastal settlements. When Louis the Pious divided his empire among his three sons (Treaty of Verdun 843), Frisia fell to Lothar. Still later it was joined to East Francia and from then on became part of the Holy Roman Empire. Situated on the fringe of Frankish territory and protected by impenetrable marshlands, the Frisians gradually managed to withdraw themselves from feudal authority. They refused to recognize any count as their lord and considered themselves immediately subordinated only to the Holy Roman Emperor, a process that was concluded somewhere in the late eleventh, early twelfth century (Bremmer 2019a: 3-10). This resulted in a conglomeration of politically loosely connected lands, some twenty in number, each of which with its own territorial administration (Vries 2015). This situation of freedom from territorial lordship lasted until about 1500, when eventually local chieftains had ascended to lordly positions in the Frisian lands east of the Ems and the lands west of this river had been subdued by the Duke of Saxony with the blessing of the Holy Roman Empire.

Old Frisian first appears in writing in an ecclesiastical context, not wholly suprisingly, since well into the twelfth century only clerics were likely to be literate. The earliest vernacular texts concern fragments of two glossed psalters, from the early twelfth and late twelfth century, respectively (Langbroek 1990, 2015, 2017; Lendinara 2014). Typical for Old Frisian, though, is that the bulk of texts comprises laws and regulations. These have 
US WURK LXX (2021), p. 5

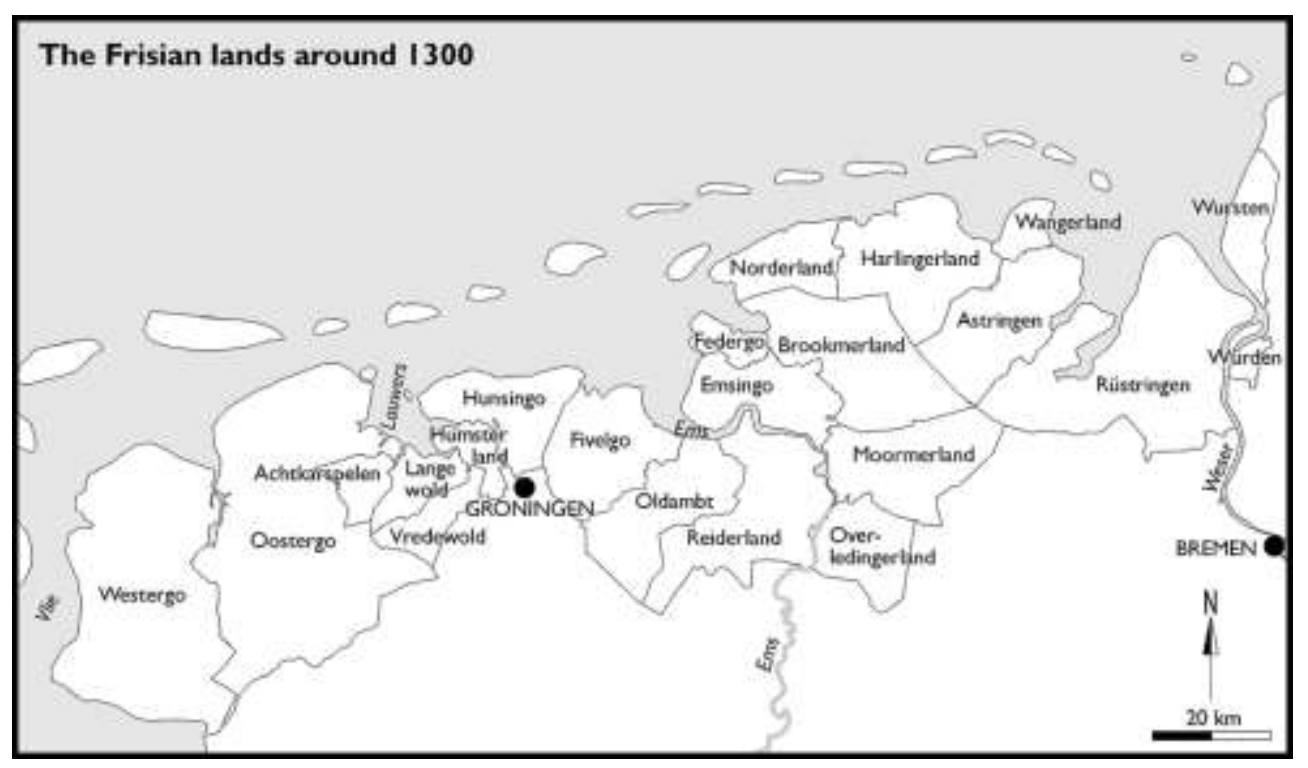

The Frisian lands around 1300. North Frisia is not included in this map.

Groningen and Bremen are given here for orientation but do not belong to the Frisian lands.

come down to us in seventeen manuscripts, dating from the second half of the thirteenth century to the end of the sixteenth century. Four of these manuscripts (R2, E4, U, Fs; for a key to the sigils, see Bremmer 2009: §14) have survived thanks to early modern antiquarians copying them. In addition, the earliest Frisian book printed, an incunable dated to 1484-1486, consists entirely of legal texts. Clearly, from 1200 to 1500, more manuscripts were circulating in the Frisian lands, also between East and West, than have survived. A considerable number of texts occur in more than one manuscript, sometimes in as many as seven, testifying to the existence of a Pan-Frisian textual community (Bremmer 2021). For a survey of multipleversion texts, see Bremmer (2009: 15). Most of the manuscripts, especially those from east of the Lauwers, have received modern editions, both diplomatically and critically. For surveys of these editions, see Johnston (2001) and Bremmer (2009: 13-14). To these add Sytsema (2012).

\section{The text corpus}

The Old Frisian textual legacy consists predominantly of legal texts and administrative documents (charters, accounts of court sessions, ledgers, etc.) (Vries 2001a). Historiographical texts come second, at a long distance. All 


\section{US WURK LXX (2021), p. 6}

the other popular medieval genres, such as homilies, hagiography, devotional and pastoral tracts, romances, scientific and utilitarian prose, lyrical poetry, are absent. This scarcity in genres does not necessarily make for dull reading.

The laws can be approached from various angles. They can be appreciated for their language and style, but also for the many windows they offer on a society that had escaped the feudal system. The Frisians acknowledged no other feudal lord than the Emperor of the Holy Roman Empire, although this acknowledgement was mere lip service. In reality, the Frisian lands were independent. Consequently, the Frisians had to formulate in writing their inherited regulations for many domains: for example, how to administer their territories, how to organize their judicial system, how to regulate succession and inheritance, how to cope with the violence of feuding and, highly important in this respect, how to calculate the compensations for physical and social injuries. In addition, a number of texts, 'synodal laws', deal with church matters.

The laws can be divided into those that are claimed to be valid in all of Frisia and those that were restricted to just one land or even to one district of a land. Furthermore, some texts were of a general nature and cannot be assigned to a specific location. To the first category belong such Pan-Frisian texts as the Seventeen Statutes $(=17 S)$ and the Twenty-four Landlaws (= $24 L$ ). The $17 S$, claiming to have Charlemagne's approval, outline how the Frisians arrange their relation with the head of the Holy Roman Empire. They sum up to what rights they are entitled regarding the tenure of ancestral land, freedom of feudal authority structures, and the peace to live a life according to long-held traditions, customs and jurisdiction. The $24 \mathrm{~L}$ concern the legal conventions that prevailed in the Frisian lands. They establish above all the mutual rights and obligations of the allodial landowners. Indicative of their importance, these two codes always appear side by side in every manuscript that contains them. Nevertheless, important as they may be, the two lack opening or closing paragraphs that state when, where and in what language they were drafted, and by whom.

The date of origin of $17 \mathrm{~K}$ and $24 \mathrm{~L}$ has remained a moot point: opinions range from the early eleventh century to the late twelfth, depending on what criteria. On numismatic grounds Henstra (2008) concluded that at least the Fifteenth Statute should be dated to 1015-1040. Since a thirteenth-century Latin version of the $17 \mathrm{~S}$ and $24 \mathrm{~L}$ is included in the Hunsingo manuscripts, earlier generations of scholars assumed this to have been the original text. However, Roeleveld (1990) convincingly demonstrated that this Latin text 


\section{US WURK LXX (2021), p. 7}

was translated from Old Frisian. Bremmer (2004: 95-97) assumed that a Latin proto-text that has not survived was translated into Frisian in the course of the twelfth century. Pragmatic texts in Middle Dutch, Middle Low German and Old Danish do not appear before 1200 (cf. Mostert 2010: 473488). It would therefore be presumptuous to claim an exceptional position in this respect for Old Frisian, especially because the two codes were written in a region that was evidently backwards with respect to cultural literacy. Popkema (2014) presents a detailed analysis of all Old Frisian legal texts until ca. 1350 and, because of the Frisian independence, draws parallels with regions outside the Holy Roman Empire rather than within it. This approach allows him to conclude that the $17 \mathrm{~S}$ and $24 \mathrm{~L}$ were most likely not translated from Latin but rather immediately composed in Frisian, thus refuting Bremmer's assumption for the opposite. Reinders (2019), too, arrives at the conclusion that these laws were directly written in the vernacular; like Popkema, she refrains from dating them. As for the place of origin, an evaluation of lexical geographical variants points to the east of the Lauwers (Munske 1973: 202-205), a conclusion that has withstood the test of time.

Internal evidence indicates that the $17 \mathrm{~S}$ precede the $24 \mathrm{~L}$ in date. A reference to the $24 \mathrm{~L}$ as an authoritative code in the Statutes of Hunsingo of 1252 suggests the code to have been well-established by then. The two codes are usually preceded in the manuscripts by a learned prologue (Murdoch 1998) that was composed after the two had been circulating for some time. It is dated, on internal evidence, to the reign of Frederick II (emperor from 1220-1250). In the fifteenth centry, lawyers started to interpret indigenous legal traditions, as expressed in the $17 \mathrm{~S}$ and the $24 \mathrm{~L}$, along lines of Romano-canonical procedural law (Hallebeek 2019).

Another Pan-Frisian text is the General Register of Compensations, which regulates in great detail the compensation to be paid for injuries. The General Register has not survived in a manuscript from the lands west of the Lauwers, but intertextual evidence demonstrates that it once circulated there too (Nijdam 2008: 94-95). In addition to the General Register, regional registers abound: there is no legal manuscript without them and their abundance testifies to the often violent character of medieval Frisian society. Feuding was endemic and necessary at the same time in order to manage the balance of power within communities (for a typical feud, see Schmidt 2005). The absence of territorial lords had frustrated the monopolizing of violence, as seen elsewhere in Western Europe, so it was up to local assemblies and, at a somewhat later stage, to communal institutions to 


\section{US WURK LXX (2021), p. 8}

administer justice, arbitrate between litigating parties and establish damages. The registers are known for their often terse prose, compact descriptions of body parts and dull enumerations of wounds and the concomitant amounts of money required for restoring the peace. On the other hand, they offer a wealth of information on the role of the body and its parts (Nijdam 2008; 2013; 2014a; 2014b; 2017; 2019), of dress (Keijzer 2015), of insult (Bremmer 1998) or of such specific topics as castration and genital mutilation (Bremmer 2013) and violent abortion (Elsakkers 2004) - all this in the context of a society steeped in violence and highly driven by concepts of honour and shame.

A further strand that runs through the Old Frisian text corpus is historiography, both in prose and in verse. Strikingly, much of it is concerned with an imagined mythical past. In one of these narratives Frisians supported Charlemagne in reconquering Rome whose citizens had imprisoned and blinded his - alleged - brother Pope Leo. In return for their audacity, Charlemagne and the Pope granted the Frisians all kinds of privileges. Another narrative claims that the Frisians, though once Christians, were defeated by the Northmen and subjected to Redbad, king of Denmark, who forced them to wear wooden collars around their necks as a token of servitude. In the fullness of time, God sent Willibrord to convert them and seek protection from the Southern king (i.e. Charlemagne). All such pseudohistoric narratives interwoven in legal texts and contexts are linked with the notion of the Frisian Freedom, that is, freedom from feudalism and, at a later stage, freedom from territorial lords. In fact, the Frisians looked upon themselves as a nation especially favoured by God. This conviction is clearly brought out in the Gesta Fresonum, a concise history of the Frisians in which events from their past are cleverly parallelled with events from the Old and New Testaments, thus relating their own history to the history of salvation (Bremmer 1995, 2019a; Johnston 1998; Nijdam and Knottnerus 2019).

Finally, interspersed between the laws occur a number of small samples of Christian imaginative literature, many of which had a wider circulation in Europe, both in Latin and the vernacular languages. These include The Fifteen Signs of Doomsday (Giliberto 2007), The Gestation of the Foetus (Elsakkers 2004: 124-134), The Creation of Adam (Murdoch 1994), The Five Keys of Wisdom (Bremmer 2014: 25-27) and more (Giliberto 2015). They show how thin the line was between law and literature. 


\section{US WURK LXX (2021), p. 9}

\section{Grammars and dictionaries}

Old Frisian was one of the first of the Old Germanic languages to be given a lexicographical description based on the new insights of historical comparative linguistics, by Karl von Richthofen (1840b), a student of Jacob Grimm. His dictionary, of encyclopaedic dimensions in its treatment of the Old Frisian vocabulary, was intended as a compendium to his magisterial edition of all the then known medieval legal texts pertaining to Frisia, whether in Latin, Old Frisian or Middle Low German (1840a). Both works have still not wholly been superseded. Holthausen (1925) is an attempt to include words from texts discovered after Richthofen (1840a) as well as corrections to Richthofen (1840b) reported by many scholars. Nevertheless, the slim book, an offshoot of Holthausen's work on an Old English etymological dictionary (Bremmer 1988), is more of a practical glossary for students rather than a serious dictionary, for it does not present words in their context. Hofmann's 1985 revision of Holthausen (1925), though welcome, was hardly adequate to cover the developments in the field in a userfriendly way. The situation is now much better, owing to Hofmann and Popkema (2008; useful reviews: Hofstra 2010; Marti 2010; Munske 2010; Seebold 2011; Smith 2012), which offers a concise dictionary of the entire Old Frisian vocabulary. However, this welcome tool is still a far cry from, e.g., the Toronto Dictionary of Old English, if only because Hofmann/Popkema do not illustrate words in example sentences. The only dictionary to offer such a presentation is Buma (1996), which is however confined to the vocabulary of one, if sizeable Old West Frisian manuscript (J). Boutkan and Siebinga (2005), despite its title Old Frisian Etymological Dictionary, covers the etymology for the vocabulary of only one Old East Frisian manuscript (R1); moreover, its contents received a mixed press (Seebold 2005; Liberman 2006; Popkema 2007). Very reliable, if restricted to uncompounded adjectives, is Faltings (2010; with addenda: Faltings 2012; useful reviews: Popkema 2011; Århammar 2013; Bichlmeier 2013).

Old East Frisian received an exhaustive, Neogrammarian grammatical treatment from van Helten (1890). For a grammar based on the texts of just one Old East Frisian manuscript (R1), see Boutkan (1996). Regrettably, Old West Frisian still lacks a comprehensive historical grammar. Regarding the didactic side, generations of students have learned Old Frisian with the help of the textbooks of either Heuser (1903) or Steller (1928), still in (re)print. Of limited practical use are Sjölin (1969), Ramat (1976) and Costello (1977). For an up-to-date textbook, see Bremmer (2009; some useful re-

views: Johnston 2010; Rauch 2011; Stevens 2011; Smith 2012). Finally, a 


\section{US WURK LXX (2021), p. 10}

handbook that is indispensable is Munske et al. (2001), since in the best of German traditions it offers an almost encyclopaedic survey of Frisian studies, paying generous attention to Old Frisian in most of its aspects. However, this handbook lacks a discussion of the stylistic and literary aspects of Old Frisian texts; indeed, there is regrettably no current introduction available on this subject. For a succinct survey in Italian, see Di Cesare (2017).

\section{Phonological issues}

One of the peculiarities of Riustring Old Frisian is its having vowel balance: high and mid vowels are in complementary distribution, a phenomenon still visible in Wursten Frisian, an early modern variety of this dialect (Smith and van Leyden 2007). The phenomenon is described by Boutkan (1996: 26-33; cf. Versloot 2001: 769-770), though he failed to take Löfstedt's Law into account, i.e. that in Riustring Old Frisian /i/ > /e/ and /u/ > /o/ before /a/ in open syllables (Bremmer 2007b: 49-50). Smith (2007) observes that Boutkan and Versloot did not take the insights of prosodic phonology into account and thus merely repeated the state-of-affairs as they were when Kock (1904) first noted the phenomenon for Old Frisian. As an alternative, Smith offers a foot-based analysis of Riustring vowel balance and explains it in terms of moraic trochees. Hermans (2009), in turn, while accepting Smith's view that Riustring Old Frisian had a moraic trochee, discarded the view of Riustring vowel balance as a kind of reduction (cf. Versloot [2008] on vowel reduction, with useful review by Liberman [2011]). Hermans argued instead that the phenomenon is best explained as a combination of two processes: Lowering and Raising. Goblirsch (2014) investigates the obstruents in Old Frisian in relation to the neighbouring languages. First belonging together with Old English and Old Saxon, they underwent Frankish influence. Frisian shared with Old/Middle English the influence of the Partial Second Consonant shift, which affected only initial position NWGmc $p, t, k$ were aspirated initially, while NWGmc $b, d, g$, were devoiced initially - in the occlusion of NWGmc $/ \gamma /$, the retention of $\mathrm{NWGmc} / \theta /$ and the restoration of voice in word-final obstruents.

\section{Morphological issues}

In view of the fairly late appearance of Old Frisian, the inherited morphological system shows signs of analogical simplification of the nominal declensions and verbal classes (cf. Bremmer 2009: ch. III). A minute analysis of the former category in a wider West Germanic context, based on a 


\section{US WURK LXX (2021), p. 11}

wealth of primary sources and secondary literature, is offered by Adamczyk (2018: ch. 4). Despite the reduction of declensional class diversity, Adamczyk concludes that 'the amount of inflectional archaism still retained in Old Frisian in its classical stage is much higher than expected in the light of the existing accounts and its late attestation date' (307). Versloot (2017b) claims to have found indirect evidence for an earlier nominative-accusative contrast in the masculine $a$-stems in manuscript $\mathrm{R} 1$ and traces of archaic instrumental and locative case-endings in manuscript E1 (Versloot 2017c).

A comprehensive analysis of the verbal system is a desideratum, but some recent inroads have been made. Strik (2014) takes stock of the changes that affected the strong verbs, concluding that overall strong inflection in Old Frisian is declining. On the other hand, Strik points out that change is not unidirectional and that some verbs may become strong. Marti Heinzle (2014) focuses on the weak verbs class 3 . She finds that traces of this small class are still detectable in Old Frisian, notably in Old East Frisian. The challenge of tackling a rare attestation of a verb is met by Stiles (2007) in a discussion of the stray forms of *sia 'to seep, to trickle' (st.vb. class I). Smith (2014) addresses the problem in Old Frisian of prefix verbs (as in G. be+spréchen 'to discuss') and particle verbs (as in G mit+kommen). She concludes that Old Frisian 'bridges the two ends of the temporal continuum of the West Germanic data' in showing that stress placement and syntactic separability are the two key factors defining the differences between prefix and particle verbs. But much work is waiting to be done on these two kinds of verbs.

The demise of the gender system, notably with respect to the relation between the neuter noun wif and its relative pronoun, is addressed by Rauch (2007) and Fleischer \& Widmer (2015). Howe (2014) and Stiles (2017) discuss the Old Frisian pronouns from a morphological angle.

\section{Lexicography and lexicology}

The study of words has always taken up a prominent position in Old Frisian studies (cf. Boutkan 2001; Bremmer 2001, 2009: ch.IV). A fine survey of word-formation is Munske (2001). The publication of Hofmann/Popkema (2008; on which see also Popkema 2008) does not mean the end of individual word studies: some fine examples are Århammar (2017) on 'world' and Lendinara (2017) on 'coal pan'. Another approach to the vocabulary is word-field studies. Especially in the field of law and legal terminology, Vries has been prolific. Many of his studies, usually written in German, appear in Vries (2012). Similar studies, conducted in the Wörter und Sachen 


\section{US WURK LXX (2021), p. 12}

tradition, are conducted by Hofmann (2009, on jewellery and luxury goods; 2013, on the production and use of clothing and other textiles; 2015a, on children; 2015b, a monograph on everyday life, reviewed Bremmer 2017c; posthumously 2020 , on old age).

\section{Syntax and style}

Syntax remains a neglected topic in Old Frisian studies. For a survey, see de Haan (2001; cf. Bremmer 2009: ch. V). In view of the frequently casuistic nature of many legal regulations, Old Frisian prose teems with sentences constructed with a hypothetical protasis of condition and an apodosis of legal consequence. Hence conditional constructions have attracted some attention. Lühr (2007) examines the various types of conditional clauses to find that they are not modelled on Latin constructions, but truly indigenous. Brennan (2019) focusses on the late-thirteenth-century Brokmonna Bref ('Charter of the Brokmer People') and concludes that 'the otherwise unusual V1-subordinate clause is systematised into a framework with the conventional, generalising means of opening a legal provision that was available to the OFris. language of law'. Bruno and Kerkhof (2019) offer a descriptive account of body part constructions, which, understandably, crop up in great numbers in the laws, and analyze the occurrence of dative experiencers in such constructions.

The style of Old Frisian prose has received more attention, notably the frequent use of alliteration. Jacob Grimm was the first to be charmed by this feature and he and successive scholars viewed it as a symptom of the antiquity of the Frisian laws. Some even suggested that they were originally composed in alliterative prose and that the alliteration served a mnemonic purpose for when the asega 'law-speaker' had to recite the law from memory at the people's assembly. More recently, this view was somewhat nuanced (Bremmer 2014: 1-3). Undoubtedly, many alliterative phrases date back to a common Germanic period, e.g., OFris mith egge and mith orde 'with edge (of sword) and point (of spear)', cf. OE ord and ecg, OS ordos endi egga, ON með oddi ok eggju. On the other hand, alliteration was also a feature of, e.g., the Latin in the Vulgate and frequently featured in Latin administrative prose. Alliteration was also felt to belong to formal legal discourse. Therefore, new alliterative collocations kept being coined that are peculiar to Frisian (Bremmer 2011).

Even today, oral deliveries characterize the legal arena. Consequently, scholars have tried to detect oral characteristics in Old Frisian legal prose and found them in the alliteration. In the past few decades, studies in orality 


\section{US WURK LXX (2021), p. 13}

have taken a great flight and opened up new possibilities to gauge the Frisian laws for their possible oral character. Notably, when Walter Ong's nine features of orally-based thought and expression are applied, they yield a rich harvest (Bremmer 2014). Additional features of oral traditions include the frequent references to 'wise men', to teacher-pupil situations and such genres as the legal riddle and proverbial wisdom (on the latter also Bremmer 2018). Also when approached from a linguistics angle, orality can be detected. Grant (2014) subjected the $17 \mathrm{~S}$ and $24 \mathrm{~L}$ in the Riustring redaction to a syntactic analysis guided by the categories and theories of Systemic Functional Linguistics. He demonstrates that when front positioning of nonsubject pronouns occurs in main clauses, thematic selections have the greatest semantic value. This phenomenon, thus Grant, is indicative of oral language. It appears that the $17 \mathrm{~S}$ exhibits more oral syntactic residue than the $24 \mathrm{~L}$, suggesting the latter are at 'a greater remove from oral culture, though by no means devoid of its influence'.

\section{Periodization}

The term 'Old Frisian' was already in use, in the sense of 'respectfully old', before Jacob Grimm formulated the well-known tripartite language periodization of 'old/middle/modern'. Hence, Old Frisian, recorded between ca. 1250 and ca. 1550, is used for the period that adjacent languages are predicated with 'middle', e.g. Middle Dutch, Middle Low German, Middle High German and Middle English. Grimm's criterion for 'old' was above all the quality of vowels in unstressed syllables. If especially case endings showed the full vowels $(/ \mathrm{u} /, / \mathrm{o} /, / \mathrm{a} /)$, these were indicative of the 'old' period'. Since Old Frisian only up to a limited extent shows full vowels in endings (e.g., -um dat.pl., -(en)a gen.pl.) it would hardly qualify to pass Grimm's test. However, scholars have pointed out that the dividing lines between periods tend to be blurred. Moreover, they differ on what criteria should be applied to identify a period as 'old', 'middle' or 'modern'. In Bremmer (2009: §218) I examine this point at length, partly in discussion with de Haan (2001b) and Versloot (2004). I conclude, with the help of criteria selected by Lass (2000), that the term 'Old Frisian' is justified, but that the language as recorded in the late fifteenth and early sixteenth centuries can better be called 'late Old Frisian'. Another useful distinction is that between Classical and Post-Classical Old Frisian. An additional criterion to the ones listed in Bremmer (2009: §218) is the voiceless/voiced dental fricative $(/ \theta /, / \delta /)$, which, unlike in the other Continental West 


\section{US WURK LXX (2021), p. 14}

Germanic languages, was retained in Frisian until the close of the Middle Ages and beyond (Laker 2014, 2017).

\section{Anglo-Frisian parallels}

The close relation between (Old) English and (Old) Frisian has been a focal point of interest amongst scholars ever since the late Middle Ages (Bremmer 1989). Lexical parallels were soon discovered and speculative explanations abounded. However, the search for solid linguistic evidence gained a firm footing in the course of the nineteenth century. The following is a selection from Bremmer (2009: §§221-225; cf. Versloot 2014c).

- Phonological parallels that were detected include nasalization and rounding of WGmc * $a$ before nasal (e.g., OE/OFris lond 'land'), fronting of WGmc $* \bar{a}>\bar{\alpha}$ (e.g. *WGmc $* d \bar{a} d->$ OE $d \bar{c} d$, OFris $d \bar{e} d$ ) and of WGmc *a $>$ OE $\alpha$, OFris $e$ (e.g., OE staf, OFris stef 'staff'), loss of nasal before voiceless fricatives with compensatory lengthening of preceding vowel (e.g. WGmc *tanp- > OE tōp, OFris tōth 'tooth'), and palatalization and assibilation of $* g$ and $* k$ before front vowels (e.g. Gmc $* g e b-a n->$ OE giefan, OFris ieva 'to give') (most recently: Laker 2007).

- Morphological parallels include the loss of person distinction in the plural forms of verbs (also in Old Saxon) and the comparative and superlative forms for 'little': OE lōessa, lēest and OFris lèssa, lèst 'less, least'. Neither OE nor OFris show gender distinction for the plural demonstrative and personal pronouns: OE $p \bar{a}$ 'those', hie 'they', OFris thā, hi $\bar{a}$. Both OE and OFris preserved the $-i$ - after the stem of weak verbs class 2 (OE macian, OFris makia). Also note the parallel endings in $u$-stems: OE/OFris dat. sg./nom.pl. - $a$ vs. Continental and NGmc $-i$.

- Unique lexical parallels between English and Frisian number well over a hundred (Löfstedt 1963-65; but note the caveat in Stiles 1995: 208-211). They are found especially in the domains of agriculture, nature and body/ health, e.g., OE cāeg/ OFris kèi 'key'; OE crohha/OFris crocha '(cast iron) pot, coal pan; OE fömne/OFris fomne 'girl'; OE löpewince/ModWFris ljip, IslandNFris liap 'lapwing, pewit' (bird); OE brcegen/OFris brein 'brain' (also ME brainepanne/OFris breinponne 'brain pan, skull'); OE wann 'dark'/OFris wonfelle 'with bruised skin'. Even ModE aye 'yes' (first recorded 1576) has an exclusive parallel in OFris ay (first recorded 1445; Howe 2017).

- Since the syntactic analysis of Old Frisian texts has remained a fairly neglected activity in Frisian studies, it is hard to say to what extent unique Anglo-Frisian parallels are a reality. In the various OGmc languages, nouns 


\section{US WURK LXX (2021), p. 15}

preceded by a numeral below twenty were inflected, e.g., twelef skillingar (nom./acc.pl), mith twelef skillingum (dat.pl.) '(with) twelve shillings'. Nouns following decads from twenty onwards usually appear in the (partitive) genitive plural, e.g., twintich skillinga 'twenty shillings'. OE and OFris uniquely show nouns in the same case as the numeral, e.g., OE mid xxxgum cyningum 'with thirty kings'/OFris mith lxxij scillingum 'with seventy-two shillings'.

One of the problems in recent discussions is to come to terms with disparities in the relative chronology of the shared Anglo-Frisian phonological parallels. Some studies have been at cross-purposes because of differing interpretations of the term 'Anglo-Frisian', as referring to closeness within a dialect continuum or, more properly, a node on a family tree. In an important and cleverly argued essay, Stiles (1995: 211) concluded that it was impossible 'to construct the exclusive common relative chronology that is necessary in order to be able to establish a node on a family tree'. He suggested therefore to banish "the term and concept of "Anglo-Frisian" from the historiography of the subject'. Fulk (1998), considering Stiles' arguments, was willing to concede that 'the Anglo-Frisian hypothesis has by no means been proved', but was unwilling to accept that Stiles had dismissed the hypothesis for good. Indeed, the discussion keeps attracting scholarly attention. Further contributions to this ongoing discussion are Kortlandt (2008; 2017; 2018), Rupanšek (2012) and Colleran (2015).

Precisely how the close linguistic relationship can be explained has proved a moot point. Apart from a mention by the Byzanthine historian Procopius (ca. 500-ca. 560), Frisians are not reported among the Germanic invaders of Britain. Place-name evidence, such as Friston and Frisby, points to settlements of individual Frisians between 700 and 1100 rather than to large groups amongst the first waves of immigrants. On the other hand, trading contacts between early Anglo-Saxon England and Frisia were intensive and may explain the shared runic innovations. Indicative of the close connections is a shared monetary union avant la lettre: the silver sceatt was minted and circulated on either side of the North Sea between ca. 680 and ca. 780. Frisian traders were active in York and London (cf. Melleno 2014). This was also the period when Anglo-Saxon missionaries, such as Willibrord, Boniface and Willehad, exerted themselves to convert the Frisians from pagans to Christians. Frisians, such as Liudger (ca. 742809), the first bishop of Münster, received their training for the priesthood in York from the famous Alcuin. 


\section{US WURK LXX (2021), p. 16}

The similarities between Old English and Old Frisian must primarily be ascribed to the common origins of Anglo-Saxons and Frisians. Instead of assuming a considerable participation of Frisians in the adventus Saxonum, it is more likely that when Angles, Saxons and Jutes moved southwards from the German Bight along the coast, a part of them settled in Frisia and adopted the name of whatever Frisians had remained (see above, p. 2). The majority crossed the North Sea to carve a piece for themselves in Britain. It so happened that the Frisians were the last continental tribe to retain the many North Sea Germanic/Ingveonic features that once prevailed along the coast of the Low Countries and Northern Germany and which the Germanic settlers had brought with them to Britain in the fifth century. When Frisia was annexed by the Franks in the course of the eighth century, one of the manifestations of their resistance would have been to withstand linguistic innovations that spread from the more central Frankish cultural centres. England remained outside this sphere of linguistic influence, owing to its insular position. Isolated by vast marshes and oriented towards the sea, Frisian likewise escaped being dominated by Franconian. Compared with the neighbouring Germanic languages, it preserved many Ingveonic features (cf. Stiles 1995). In sum, the Anglo-Frisian parallels are not the outcome of a shared origin in a hypothetical Anglo-Frisian mother dialect, as generations of linguists have claimed. They are the result of cultural developments that reach back to before and after the migration of the Anglo-Saxons to Britain (Salmons 2017). However, sometimes unique parallels are the outcome of independent developments (e.g., Bremmer 2017a). For an overview of the historic context, see Hines and IJssennagger (2017, useful reviews Laker 2019; Bremmer 2019b).

\section{Language contact}

Old Frisian shows linguistic influence from its Saxon neighbours from the first written documents. A Latin psalter interverbally glossed with Old Frisian words from around 1200 already shows Low German interference (Bremmer 2007a: 226-227). A full analysis of the extent to which Low German influence is present in the various Old Frisian - some of which contain Middle Low German texts too - manuscripts is still wanting, but some inroads into this field, notably with respect to Old East Frisian, have been made (Bremmer 1996: 9-10, 1997, 2008b; 2017b). In the course of the fifteenth century, Low German replaced Frisian as a written medium in the lands east of the River Ems (Vries 2006). Latin has also exercised its influence on Old Frisian, especially concerning the vocabulary, ranging 


\section{US WURK LXX (2021), p. 17}

from contact with the Romans to terminology related to the Christian faith and church matters (Dekker 2000; Yeandle 2007; Bremmer 2018a). Unlike the legacy of their preaching activities in other Germanic languages - e.g., OHG gotspell, OS godspel, ON guðspjall, all from OE godspell 'gospel' (Timofeeva 2017: 223) - Anglo-Saxon missionaries, though present in considerable numbers in Frisia from the late seventh century onwards, left no traces of Old English Christian terminology in the Frisian language. Towards the close of the Middle Ages, Middle Dutch increasingly started to make its presence felt in spelling, vocabulary and grammar (Blom 2007). Eventually Low German replaced Frisian as a written language, west of the River Ems and east of the River Lauwers from the early fifteenth century (Niebaum 2001) until ca. 1600, after which Dutch took over. Dutch also replaced Frisian as the written medium west of the Lauwers in the sixteenth century (Vries 2001).

$* * *$

Since Frisian never acquired the status of a national language, the study of Old Frisian, like that of Old Saxon, has lacked the same academic and governmental support that national languages benefit from. This survey will make clear once more that Old Frisian in many aspects is so interesting and challenging that it attracts scholars from far and wide. Not impressive in number, perhaps, but remarkably committed. It is my express hope that this review will contribute to increasing this number. ${ }^{2}$

Universiteit Leiden/Fryske Akademy

r.h.bremmer@hum.leidenuniv.nl

2. My gratitude for welcome comments, corrections and advice is due to Michiel de Vaan, Jarich Hoekstra, Stephen Laker, Annet Nieuwhof, Anne Popkema, Patrick Stiles, Arjen Versloot, and Oebele Vries. 


\section{US WURK LXX (2021), p. 18}

\section{REFERENCES}

$A B \ddot{G} G=$ Amsterdamer Beiträge zur älteren Germanistik NOWELE $=$ North-Western European Language Evolution

$U W=U s$ Wurk. Tydskrift foar Frisistyk/Journal of Frisian Studies (open access: https://ugp.rug.nl/uswurk)

Adamczyk, Elżbieta. 2018. Reshaping of the Nominal Inflection in Early Northern West Germanic. NOWELE Supplement 31. Amsterdam: John Benjamins.

Århammar, Nils. 1990. 'Friesisch und Sächsisch. Zur Problematik ihrer gegenseitigen Abgrenzung im Früh- und Hochmittelalter'. In Bremmer et al. (1990), $1-25$.

Århammar, Nils. 2001. 'Die Herkunft der Nordfriesen und des Nordfriesischen'. In Munske et al. (2001), 531-537.

Århammar, Nils. 2013. Review of Faltings (2010) in Zeitschrift für Dialektologie und Linguistik 80.1: 77-89.

Århammar, Nils. 2017. 'Die friesischen Wortformen des Etymons Welt (World) in Zeit und Raum: Erb vs. Lehnlautungen'. In Laker and de Vaan (2017), 5-36.

Algra, Nicolaas E. 2003. 'The Lex Frisionum: the Genesis of a Legalized Life'. In Ferdinand J.M. Feldbrugge (ed.), The Law's Beginnings. The Hague: Martinus Nijhoff, 77-92.

Bazelmans, Jos. 2002. 'Die spätrömerzeitliche Besiedlungslücke im niederländischen Küstengebiet und das Fortbestehen des Friesennamens', Emder Jahrbuch für historische Landeskunde Ostfrieslands 81: 7-61.

Bazelmans, Jos. 2009. 'The Early-medieval Use of Ethnic Names from Classical Antiquity. The Case of the Frisians'. In T. Derks and N. Roymans (eds.), Ethnic Constructs in Antiquity. The Role of Power and Tradition (= Amsterdam Archaeological Studies 13), Amsterdam: Amsterdam University Press, 321-337.

Bleck, Reinhold. 2016. Angelsächsische oder friesische Runen auf Goldstücken des 6. und 7. Jahrhunderts (Goldbrakteaten, Solidi und Tremisses). Göppinger Arbeiten zur Germanistik 784. Göppingen: Kummerle Verlag.

Bammesberger, Alfred. 1996. 'Frisian and Anglo-Saxon Runes from the Linguistic Angle'. In Looijenga and Quak 1996: 15-23.

Bammesberger, Alfred. 1999. 'Runic Frisian weladu and Further West Germanic Nominal Forms in -u'. NOWELE 33: 121-132.

Bichlmeier, Harald. 2013. Review of Faltings (2010), Kratylos 58 (2013), 137- 42.

Blok, Dirk P. 1996. 'Das Alter der friesischen Wurtnamen'. In Looijenga and Quak 1995: 25-33.

Blom, Alderik. 2007. 'Language Admixture in the Old West Frisian Basle Wedding Speeches?' In Bremmer et al. (2007), 1-27.

Boutkan, Dirk. 1996. A Concise Grammar of the Old Frisian Dialect of the First Riustring Manuscript. NOWELE Suppl. 16. Odense: Odense University Press. 


\section{US WURK LXX (2021), p. 19}

Boutkan, Dirk. 2001. 'Lexicology of Old Frisian'. In Munske et al. (2001), 647653.

Boutkan, Dirk, and Sjoerd M. Siebinga. 2005. Old Frisian Etymological Dictionary. Leiden: Brill.

Bremmer Jr, Rolf H. 1988. 'The Old Frisian Component in Holthausen's Altenglisches etymologisches Wörterbuch'. Anglo-Saxon England 17, 5-13.

Bremmer Jr, Rolf H. 1989. 'Late Medieval and Early Modern Opinions on the Affinity between English and Frisian: the Growth of a Commonplace'. Folia Linguistica Historica 9, 167-191.

Bremmer Jr, Rolf H. 1992. A Bibliographical Guide to Old Frisian Studies. NOWELE Supplement, vol. 9. Odense: Odense University Press.

Bremmer Jr, Rolf H. 1992b. 'Willibrord through Anglo-Saxon and Frisian Eyes: from History to Myth'. In Volkert F. Faltings et al. (eds.). Friesische Studien I. NOWELE Suppl. 8. Odense: Odense University Press, 1-28.

Bremmer Jr, Rolf H. 1996. 'Old Frisian Dialectology and the Position of the "Ommelanden"'. In Adeline Petersen and Hans Frede Nielsen (eds.), A Frisian and Germanic Miscellany Published in Honour of Nils Århammar. Odense: Odense University Press, 1-18 (= NOWELE 28/29).

Bremmer Jr, Rolf H. 1997. 'Bad Frisian and Bad Low German: Interferences in the Writings of a Medieval West Frisian'. Multilingua 16: 375-388.

Bremmer Jr, Rolf H. 1998. 'Insults Hurt: Verbal Injury in Late Medieval Frisia'. In Bremmer et al. (1998), 89-112.

Bremmer Jr, Rolf H. 2001. 'Lexicography of Old Frisian'. In Munske et al. (2001), 653-657.

Bremmer Jr, Rolf H. 2005. "Old Frisian fule and felo "much; many": an Idiosyncracy in Germanic and Frisian Perspective'. NOWELE 46/47: 31-40.

Bremmer Jr, Rolf H. 2007a. 'Footprints of Monastic Instruction: a Latin Psalter with Interverbal Old Frisian Glosses'. In Sarah Larratt Keefer and Rolf H. Bremmer Jr (eds.). Space, Text and Margin in Medieval Manuscripts. Leuven: Peeters, 203-233.

Bremmer Jr, Rolf H. 2007b. 'Language and Contents of the Old Frisian Manuscripts from Rüstringen (c.1300): a "Veritable Mixtum Compositum". In Bremmer et al. (2007), 29-64.

Bremmer Jr., Rolf H. 2008a. 'North-Sea Germanic at the Cross-Roads: the Emergence of Frisian and Hollandish'. NOWELE 54/55, 278-308.

Bremmer Jr, Rolf H. 2008b. 'Saxon Loans in Rüstring Frisian'. In Kees Dekker, Alasdair MacDonald and Hermann Niebaum (eds.), Northern Voices. Essays on Old Germanic and Related Topics, Offered to Professor Tette Hofstra. Leuven: Peeters, 191-201.

Bremmer Jr, Rolf H. 2009. An Introduction to Old Frisian. History, Grammar, Reader, Glossary. Amsterdam: John Benjamins. 


\section{US WURK LXX (2021), p. 20}

Bremmer Jr, Rolf H. 2011. 'Dealing Dooms: Alliteration in the Old Frisian Laws'. In Jonathan Roper (ed.), Alliteration in Culture. Basingstoke, Palgrave/MacMillan, 74-92.

Bremmer Jr, Rolf H. 2013. 'The Children He Never Had; the Husband She Never Served: Castration and Genital Mutilation in Medieval Frisian Law'. In Larissa Tracy (ed.). Castration and Culture in the Middle Ages. Cambridge: D. S. Brewer, 108-130.

Bremmer Jr, Rolf H. 2014. 'The Orality of Old Frisian Law Texts'. In Bremmer et al. (2014), 1-48.

Bremmer Jr, Rolf H. 2017a. 'Old English būtan / Old Frisian būta: from Adverb to Conjunction. Another Anglo-Frisian Parallel?', ABäG 77: 601-615.

Bremmer Jr, Rolf H. 2017b. 'Language Contact in Medieval Frisia: Middle Low German Spelling Interferences in Old East Frisian Manuscripts', Filologia Germanica - Germanic Philology 9: 1-18.

Bremmer Jr, Rolf H. 2017c. Review of Hofmann (2015b) in UW 66: 84-89.

Bremmer Jr, Rolf H. 2018a. 'Latin Loans in Old Frisian and the Problem of Relative Chronology'. In Claudia Di Sciacca, Concetta Giliberto, Carmela Rizzo and Loredana Teresi (eds.), Studies on Late Antique and Medieval Germanic Glossography and Lexicography in Honour of Patrizia Lendinara, 2 vols. Pisa: Edizioni ETS, 39-57.

Bremmer Jr, Rolf H. 2018b. "“The Fleeing Foot is the Confessing Hand". Proverbs in the Old Frisian Laws'. In Marina Cometta et al. (eds.). La tradizione gnomica nelle letterature germaniche medievali. Milan: di/ segni, 79-100.

Bremmer Jr, Rolf H. 2019a. 'Thi Wilde Witsing: Vikings and Otherness in the Old Frisian Laws', Journal of English and Germanic Philology 119.1: 1-26.

Bremmer Jr, Rolf H. 2019b. Review of Hines and IJssennagger (2017) in Early Medieval Europe 27.3: 323-325.

Bremmer Jr, Rolf H. 2021. 'More than Language: Law and Textual Communities in Medieval Frisia'. In Thom Gobbitt (ed.), Law | Book | Culture in the Middle Ages. Leiden: Brill, 98-125.

Bremmer Jr, Rolf H., Geart van der Meer and Oebele Vries (eds.). 1990. Aspects of Old Frisian Philology. Amsterdam: Rodopi (= ABäG 31/32).

Bremmer Jr, Rolf H., Thomas S. B. Johnston and Oebele Vries (eds.). 1998. Approaches to Old Frisian Philology. Amsterdam: Rodopi 1998 (= ABäG 49).

Bremmer, Rolf H. Jr, Stephen Laker and Oebele Vries (eds.). 2007. Advances in Old Frisian Philology. Amsterdam: Rodopi (= ABäG 64).

Bremmer, Rolf H. Jr, Stephen Laker and Oebele Vries (eds.). 2014. Directions for Old Frisian Philology. Amsterdam: Rodopi (= ABäG 73).

Brennan, Rolland K. 2019. 'Conditional Sentences in the Old East Frisian Brokmonna Bref'. NOWELE 72.1: 11-141.

Bruno, Laura, and Peter Alexander Kerkhof. 2019. 'Bodily Injuries and Dative Experiencers in Old Frisian'. ABäG 79: 485-516 


\section{US WURK LXX (2021), p. 21}

Buma, Wybren Jan. 1996. Vollständiges Wörterbuch zum westerlauwerschen Jus Municipale Frisonum. Leeuwarden: Fryske Akademy.

Colleran, Rebecca. 2015. "To Have" and "to Have to": Addressing OFr Inheritance through Auxiliation'. Philologia Frisica anno 2014, 41-63.

Costello, John R. 1977. A Generative Grammar of Old Frisian. Bern: Peter Lang.

Dekker, Kees. 2000. 'Between Rome and Rüstringen: Latin Loan Words in Old Frisian'. Philologia Frisica anno 1999, 27-58.

de Haan, Germen. 2001a. 'Syntax of Old Frisian'. In Munske et al. (2001), 626636.

de Haan, Germen. 2001b. 'Why Old Frisian is Really Middle Frisian'. Folia Linguistica Historica 22: 179-206.

de Vaan, Michiel. 2011. 'West Germanic *ai in Frisian'. ABäG 67: 301-314.

de Vaan, Michiel. 2017. The Dawn of Dutch: Language Contact in the Western Low Countries before 1200. NOWELE Supplement, vol. 30. Amsterdam: John Benjamins.

Di Cesare, Giulio G. S. 2017. 'La letteratura frisone medioevale'. In Marco Battaglia (ed.). La civiltà letterarie del Medioevo germanico. Rome: Carocci editore, 309-344.

Elsakkers, Marjanne. 2004 'Her anda neylar: an Intriguing Criterion for Abortion in Old Frisian Law'. Scientiarum Historia. Tijdschrift voor de Geschiedenis van de Wetenschappen en de Geneeskunde 30.1: 107-154.

Faltings, Volkert F. 2010. Etymologisches Wörterbuch der friesischen Adjektiva. Berlin: de Gruyter.

Faltings, Volkert F. 2012. 'Ergänzende Bemerkungen und Addenda zum Etymologischen Wörterbuch der friesischen Adjektiva'. NOWELE 64/65: 11738.

Faltings, Volkert F., Alastair G.H. Walker and Ommo Wilts (eds.). 1995. Friesische Studien II. NOWELE Supplement, vol. 12. Odense: Odense University Press.

Fleischer, Jürg, and Paul Widmer. 2015. 'When Lexical Hybrids Become Feminine: the Declension of wif 'woman; wife' in Old Frisian and Modern Frisian Varieties'. Philologia Frisia anno 2014: 219-239.

Fulk, Robert D. 1998. 'The Chronology of Anglo-Frisian Sound Changes'. In Bremmer et al. (1998), 139-154.

Giliberto, Concetta. 1998. 'The Criteria for the Formation of the Frisian Runic Corpus Revisited'. In Bremmer, Rolf H. Jr, Thomas S.B. Johnston and Oebele Vries (eds.). Approaches to Old Frisian Philology. Amsterdam: Rodopi, 155168 (= ABäG 49).

Giliberto, Concetta. 2000. Le iscrizioni runiche sullo sfondo della cultura frisone altomedievale. Göppinger Arbeiten zur Germanistik 679. Göppingen: Kummerle Verlag.

Giliberto, Concetta. 2007. 'The Fifteen Signs of Doomsday of the First Riustring Manuscript'. In Bremmer et al. (2007), 129-152. 


\section{US WURK LXX (2021), p. 22}

Giliberto, Concetta. 2015. 'Theological and Doctrinal Texts in the Old Frisian Thet Authentica Riocht'. Philologia Frisica anno 2004: 136-153.

Goblirsch, Kurt. 2014. 'Between Saxon, Franconian, and Danish: the Obstruents of Frisian'. In Bremmer et al. (2014), 95-118.

Graf, Martin H. 2019. Review of Bleck 2016 in Futhark. International Journal of Runic Studies 8: 167-171.

Grant, Colin J. 2014. 'Two Aspects of Nominal Style in the Seventeen Stututes and Twent-four Landlaws'. In Bremmer et al. (2014), 119-144.

Grønvik, Ottar. 1994. 'Zur Deutung der Runeninschrift von Westeremden B'. In James E. Knirk (ed.), Proceedings of the Third International Symposium on Runes and Runic Inscriptions. Uppsala: Institutionen för nordiska språk vid Uppsala Universitet, 95-104.

Hallebeek, Jan. 2019. 'The Gloss to the Saunteen Kesta (Seventeen Statutes) of the Frisian Land Law'. Legal History Review 87: 30-64.

Heinzle, Mirjam Marti. 2014. 'Die schwachen Verben der dritten Klasse im Altfriesischen - eine Spurensuche'. In Bremmer et al. (2014), 145-184.

Henstra, Dirk Jan. 2008 'Fon jelde en de datering van de vijftiende algemeenFriese Keur'. It Beaken 70: 289-296.

Hermans, Ben. 2009. 'The Strength of Posttonic Syllables in Riustring Old Frisian'. Philologia Frisica anno 2008, 74-101.

Heuser, Wilhelm. 1903. Altfriesisches Lesebuch mit Grammatik und Glossar. Heidelberg: Winter.

Hines, John, and Nelleke IJssennagger (eds.). 2017. Frisians and Their North Sea Neighbours from the Fifth Century to the Viking Age. Woodbridge: Boydell.

Hofmann, Gisela. 2009. 'Gold, Silber, Kleinodien, kostbare Gewänder und Gebrauchsgegenstände aus Edelmetall im mitteralterlichen Friesland'. UW 58: 73-146.

Hofmann, Gisela. 2013. 'Herstellung und Gebrauch von Kleidung und andere Textilien im alten Friesland'. $U W$ 62: 87-160.

Hofmann, Gisela. 2015a. 'Das Kind im alten Friesland. Zeugnisse aus vornehmlich altfriesischen Schriftquellen'. UW 64: 11-48.

Hofmann, Gisela. 2015b. Mittelalterliches Alltagsleben im Spiegel der altfriesischen Terminologie mit Ergänzungen aus zeitgenössischen niederländischen Quellen. Estrikken 98. Groningen: FFYRUG.

Hofmann, Gisela. 2020. 'Betagte Menschen im alten Friesland. Zeugnisse über alte Menschen in altfriesischen Rechtstexten und Urkunden sowie bei Geschichtsschreibern'. UW 69: 115-170.

Hofmann, Dietrich, and Anne T. Popkema. 2008. Altfriesisches Handwörterbuch. Heidelberg: Winter.

Hofstra, Tette. 2003. 'Altfriesisch und Altniederländisch'. In Pijnenburg et al. (2003), 77-91.

Hofstra, Tette. 2010. Review of Hofmann/Popkema (2008) in UW 59 (2010), 79 85. 


\section{US WURK LXX (2021), p. 23}

Howe, Stephen, 2014. 'Old Frisian Personal Pronouns: Morphology and Change'. In Bremmer et al. (2014), 201-242.

Howe, Stephen. 2017. 'Aye-ay: an Anglo-Frisian Parallel'. In Laker and de Vaan (2017), 210-242.

Howell, Robert B. 2012. Review of Bremmer (2009) in Journal of Germanic Linguistics 24.3: 271-275.

Johnston, Thomas S.B. 1998. 'Old Frisian Law and the Frisian Freedom Ideology: Text and Manuscript Composition as a Marketing Device'. In Bremmer et al. (1998), 179-214.

Johnston, Thomas S.B. 2001. 'The Old Frisian Law Manuscripts and Law Texts'. In Munske et al. (2001), 571-587.

Johnston, Thomas S. B. 2010. Review of Bremmer (2009) in UW 59: 158-162.

Keijzer, Daan. 2015. 'Cloth as Currency: Clothing and the Naked in Old Frisian Law'. $U W$ 64: 71-89.

Kock, Axel. 1904. 'Vokalbalance im Altfriesischen'. Beiträge zur Geschichte der deutschen Sprache und Literatur 32: 175-193.

Kortlandt, Frederik. 2008. 'Anglo-Frisian'. NOWELE 54/55: 265-278.

Kortlandt, Frederik. 2017. 'Old English and Old Frisian'. UW 66: 122-127.

Kortlandt, Frederik. 2018. "Anglo-Frisian "here", "there", "where". $U W$ 67: 97103.

Laker, Stephen. 2007. 'Palatalization of Velars: a Major Link of Old English and Old Frisian'. In Bremmer et al. (2007), 165-184.

Laker, Stephen. 2014. 'The Downfall of Dental Fricatives: Frisian Perspectives on a Wider Germanic Trend'. In Bremmer et al. (2014), 261-300.

Laker, Stephen. 2017. 'Early Changes of Dental Fricatives: English and Frisian Compared'. In Laker and de Vaan (2017), 243-267.

Laker, Stephen. 2019. Review of Hines and IJssennager (2017) in Speculum 94.3: 842-844.

Laker, Stephen, and Michiel de Vaan (eds.). 2017. Frisian through the Ages. Festschrift für Rolf H. Bremmer Jr. Leiden: Brill.

Langbroek, Erika. 1990. 'Condensa et tenebrosa. Die altfriesischen Psalmen: Neulesung und Rekonstruktion (UB Groningen Hs 404)'. In Bremmer et al. (1990), 255-284.

Langbroek, Erika. 2015. 'So viel geschrieben, so wenig geblieben. Eine neue Entdeckung: unbekannte altfriesiche Psalmglossen'. ABäG 74: 135-146.

Lass, Roger. 2000. 'Language Periodization and the Concept of "Middle". In I. Taavitsainen, Tertu Nevalainen and Matti Rissanen (eds.), Placing Middle English in Context. Berlin: de Gruyter, 7-41.

Lendinara, Patrizia. 2014. 'Glossing the Old Frisian Psalter: Pragmatics and Competence'. In Bremmer et al. (2014), 301-327.

Lendinara, Patrizia. 2017. 'Old Frisian krocha: Setting Fire with a Coal Pan'. In Laker and de Vaan (2017), 280-302. 


\section{US WURK LXX (2021), p. 24}

Liberman, Anatoly. 2006. Review of Boutkan and Siebinga (2005) In Trefwoord: $1-15$.

Liberman, Anatoly. 2011. Review of Versloot (2008) in NOWELE 60/61: 211-219.

Löfstedt, Ernst. 1963-65. 'Beiträge zur nordseegermanischen und nordseegermanisch-nordischen Lexikographie'. Niederdeutsche Mitteilungen 19-21: 281-345; 22: 39-64; 25: 25-39.

Looijenga, Tineke, and Arend Quak (eds.). 1996. Frisian Runes and Neighbouring Traditions. Proceedings of the First International Symposium on Frisian Runes at the Fries Museum, Leeuwarden 26-29 January 1994. Amsterdam: Rodopi (= $A B \ddot{a} G$ 45).

Looijenga, Tineke. 2003. Texts \& Contetxs of the Oldest Runic Inscritpions. Leiden: Brill.

Marti, Mirjam. 2010. Review of Hofmann/Popkema (2008) in Beiträge zur Namenkunde 45: 236-239.

Marti, Mirjam. 2011. Review of Bremmer (2009) in Beiträge zur Geschichte der deutschen Sprache und Literatur 133: 121-124.

Melleno, Daniel. 2014. 'North Sea Networks: Trade and Communication from the Seventh to the Tenth Century'. Comitatus 46: 45-89.

Mostert, Marco. 2010. 'The Early History of Written Culture in the Northern Netherlands'. In Slavica Ranković (ed.), Along the Oral-Written Continuum. Types of Texts, Relations and Their Implications. Turnhout: Brepols, 449-488.

Munske, Horst H. 1973. Der germanische Rechtswortschatz im Bereich der Missetaten. Philologische und sprachgeographische Untersuchungen. Berlin: de Gruyter.

Munske, Horst H. 2001. 'Wortbildung des Altfriesischen'. In Munske et al. (2001), 636-647.

Munske, Horst H., et al. (eds.). 2001. Handbuch des Friesischen/Handbook of Frisian Studies. Tübingen: Max Niemeyer.

Murdoch, Brian. 1994. 'The Old Frisian Adam octopartitus', ABäG 40: 131-138.

Murdoch, Brian. 1998. 'Authority and Authenticity: Comments on the Prologue to the Old Frisian Laws'. In Bremmer (1998), 215-244.

Niebaum, Hermann. 2001. 'Der Niedergang des Friesischen zwischen Lauwers und Weser'. In Munske et al. (2001), 430-442.

Nielsen, Hans Frede. 1981. 'Old Frisian and the Old English Dialects'. UW 30: 4966.

Nielsen, Hans Frede. 1993. 'Runic Frisian skanomodu and ainiwulufu and the Relative Chronology of Monophthongization and i-Mutation'. NOWELE 21/22: 81-88.

Nielsen, Hans Frede. 1994. 'Ante-Old Frisian: A Review'. NOWELE 24.1: 91-136.

Nielsen, Hans Frede. 1995. 'The Emergence of the os and ac Runes in the Runic Inscriptions of England and Frisia: A Linguistic Assessment'. In Faltings et al. (1995), 19-34. 


\section{US WURK LXX (2021), p. 25}

Nielsen, Hans Frede. 1996. 'Friesen. Runeninschriften'. Reallexikon der germanischen Altertumskunde, vol. 10: 28-35.

Nielsen, Hans Frede. 2001. 'Frisian and the Grouping of the Older Germanic Languages'. In Munske et al. (2001), 512-523.

Nieuwhof, Annet. 2013. 'Anglo-Saxon Immigration or Continuity? Ezinge and the Coastal Area of the Northern Netherlands in the Migration Period'. Journal of Archaeology in the Low Countries 5.1: 53-83.

Nieuwhof, Annet (ed.). 2020. The Excavations at Wijnaldum. Vol. 2: HandThrown and Wheel-Made Pottery of the First Millenium AD. Groningen Archaeological Studies 36. Eelde: Barkhuis.

Nijdam, Han. 2008. Lichaam, eer en recht in middeleeuws Friesland. Een studie naar de Oudfriese boeteregisters. Hilversum: Verloren.

Nijdam, Han. 2013. 'Honour and Shame Embodied. The Case of Medieval Frisia'. In Bénédicte Sère and Jörg Wettlaufer (eds.). Shame between Punishment and Penance. The Social Usages of Shame in the Middle Ages and Early Modern Times / La honte entre peine et pénitence - les usages sociaux de la honte au Moyen Âge et aux débuts de l'époque moderne. Florence: Galluzzo, 65-88.

Nijdam, Han. 2014. 'Indigenous or Universal? A Comparative Perspective on Medieval (Frisian) Compensation Law'. In Per Andersen et al. (eds.). How Nordic are the Nordic Medival Laws? - Ten Years After. Copenhagen: Djøf Forlag, 161-181.

Nijdam, Han. 2014. 'Compensating Body and Honor: the Old Frisian Compensation Tarriffs'. In W. J. Turner and S. M. Butler (eds.). Medicine and Law in the Middle Ages. Leiden: Brill, 25-57.

Nijdam, Han. 2017. 'A Comparison of the Injury Tariffs in the Early Kentish and the Frisian Law Codes'. In Hines and IJssennagger (eds.) 2017, 223-241.

Nijdam, Han. 2019. 'The Body Legal in Frisian Law: Bridging the Gap Between the Lex Frisionum and the Old Frisian Compensation Tariffs'. In Stefan Jurasinski and Andrew Rabin (eds.), Languages of the Law in Early Medieval England. Essays in Memory of Lisi Oliver. Louvain: Peeters, 101-126.

Nijdam, Han, and Otto Knottnerus. 2019. 'Redbad, the Once and Future King of the Frisians'. In Simon Halink (ed.). Northern Myths, Modern Identities: the Nationalisation of Northern Mythologies since 1800. Leiden: Brill, 87-114.

Page, Raymond I. 2001. 'Frisian Runic Inscriptions'. In Munske et al. (2001), 523530.

Parsons, David. 1996. "The Origins and Chronology of the "Anglo-Frisian" Additional Runes'. In Looijenga and Quak (1996), 151-170.

Pijnenburg, Willy, Arend Quak and Tanneke Schoonheim (eds.). 2003. 'Quod vulgo dicitur': Studien zum Altniederländischen. Amsterdam: Rodopi $(=A B \ddot{a} G$ 57).

Popkema, Anne T. 2007. Review of Boutkan and Siebinga (2005) in ABäG 63 (2007), 291-296. 


\section{US WURK LXX (2021), p. 26}

Popkema, Anne T. 2008. 'A New Step in Old Frisian Lexicography: the Altfriesisches Handwörterbuch'. In Marijke Mooijaart and Marijke van der Wal (eds.). Yesterday's Words. Contemporary, Current and Future Lexicography. Newcastle: Cambridge Scholars Press, 110-123.

Popkema, Anne T. 2011. Review of Faltings (2010) in It Beaken 73: 188-193.

Popkema, Anne T. 2014. 'Old Frisian: a Legal Language in Principle'. In Bremmer et al. (2014), 369-395.

Quak, Arend. 1996. 'Friese persoonsnamen in de oudste bronnen'. Fryske Nammen 10: $155-69$.

Quak, Arend. 2003. 'Altfriesisches in altniederländischen Ortsnamen'. In Pijnenburg et al. (2003), 281-310.

Quak, Arend. 2010. 'Verhältnis der altfriesischen Runeninschriften zu den anderen Traditionen'. In Zentrale Probleme bei der Erforschung der älteren Runen: Akten einer internationalen Tagung an der Norwegischen Akademie der Wissenschaften, ed. John Ole Askedal et al. Frankfurt a.M.: Lang, 151-162.

Quak, Arend. 2012. 'Het oudste Oudfries'. Philologia Frisica anno 2008: 57-74.

Quak, Arend. 2016. Review of Bleck (2016) in ABäG 76.4: 566-573.

Ramat, Paolo. 1976. Das Friesische. Eine sprachliche und kulturgeschichtliche Einführung. Innsbrucker Beiträge zur Sprachwissenschaft 16. Innsbruck: Inst. der Sprachwissenschaft Universität Innsbruck.

Rauch, Irmengard. 2007. 'Gender Semiotics, Anglo-Frisian wīf, and Old Frisian Noun Gender'. In Bremmer et al. (2007), 357-366.

Rauch, Irmengard. 2011. Review of Bremmer (2009) in NOWELE 60/61: 199-203.

Reinders, Ann-Kathrin. 2019. 'Die Sprache der erstmaligen Verschriftlichung der 17 Küren un der 24 Landrechte - Altfriesisch oder Latein?'. UW 68: 99-118.

Roeleveld, Annelies. 1990. 'Providentia et plicht: the Old Frisian Words in the Latin Texts of the Hunsingo Manuscripts'. In Bremmer et al. (1990), 371-390.

Rupanšek, Luka. 2012. 'Remarks on the Development of the "Anglo-Frisian" Vowel System'. NOWELE 64/65: 77-90.

Salmon, Joseph. 2017. 'The Anglo-Frisian Relationship as Contact and Linkage'. In Laker and de Vaan (2017), 377-388.

Schmidt, Heinrich. 2005. 'Eine friesische Fehde: Die "Menalda-Fehde" von 1295'. In Heinrich Schmidt et al. (eds.). Tota Frisia in Teilansichten. Hajo van Lengen zum 65. Geburtstag. Aurich: Das Ostfriesische Landschaft, 143-172.

Schneider, Jens. 2011. 'The Frisians' Ethnogenesis'. Revue du Nord 93(391), 749759.

Seebold, Elmar. 2005. Review of Boutkan and Siebinga (2005) in UW 54 (2005), 202-205.

Seebold, Elmar. 2010. Review of Hofmann/Popkema (2008) in NOWELE 60/61, 205-209.

Sjölin, Bo. Einführung in das Friesische. Stuttgart: J. B. Metzler.

Smith, Laura C. 2007. 'Old Frisian Vowel Balance and Its Relationship to West Germanic Apocope and Syncope’. In Bremmer et al. (2007), 379-410. 


\section{US WURK LXX (2021), p. 27}

Smith, Laura C. 2012. "Old Frisian: Renewed Interest in an "Old" Germanic Language'. Diachronica 29: 98-115.

Smith, Laura C. 2014. 'Particle and Prefix Verbs: Insights from the History of Frisian and Other West Germanic Languages'. In Bremmer et al. (2014), 421448.

Smith, Norval, and Klaske van Leyden. 2007. 'The Unusual Outcome of a LevelStress Situation: The Case of Wursten Frisian'. NOWELE 52: 31-66.

Steller, Walther. 1928. Abriss der altfriesischen Grammatik ... mit Lesestücken und Wortverzeichnis. Halle (Saale): Niemeyer.

Stevens, Christopher M. 2011. Review of Bremmer (2009) in Speculum 86: 168169.

Stiles, Patrick V. 1995. 'Remarks on the "Anglo-Frisian" Thesis'. In Faltings et al. (1995), 177-220.

Stiles, Patrick V. 2007. 'The Emergence of Old Frisian *siä "to seep, trickle"'. UW 56: $125-134$.

Stiles, Patrick V. 2017. 'The Comparative Method, Internal Reconstruction, Areal Norms and the West Germanic Third Person Pronoun'. In Laker and de Vaan (2017), 410-441.

Strik, Oscar. 2014. 'Stability and Change in Strong Verb Inflection between Old and Early Modern Frisian'. In Bremmer (2014), 449-496.

Sytsema, Johanneke. 2012. A Diplomatic Edition of Codex Unia. https://tdb.fryskeakademy.eu/tdb/index-unia-en.html

Timofeeva, Olga. 2017. 'Lexical Loans and Their Diffusion in Old English: of "gospels", "martyrs", and "teachers". Studia Neophilologica 89.2: 215-237.

van Helten, Willem L. 1890. Altostfriesische Grammatik. Leeuwarden: Meijer.

Versloot, 2004. 'Why Old Frisian is Still Quite Old'. Folia Linguistica Historica 25: 253-298.

Versloot, Arjen P. 2008. Mechanisms of Language Change: Vowel Reduction in 15th Century West Frisian. Utrecht: LOT (Ph.D. Thesis University of Groningen).

Versloot, Arjen P. 2014a. 'The Runic Frisian Vowel System. The Earliest History of Frisian and Proto-Insular North Frisian'. $A B \ddot{a} G$ 72: 35-62.

Versloot, Arjen P. 2014b. 'Die - ar-Plrale im Altwestfriesischen mit einem Exkurs über die sachlichen Plurale im Westfriesischen'. $U W$ 63: 93-114.

Versloot, Arjen P. 2014c. 'Methodological Reflections on the Emergence of Old Frisian'. NOWELE 67.1: 23-49.

Versloot, Arjen P. 2015. 'Die "friesischen" Wörter in der Lex Frisionum'. UW 64: $1-10$.

Versloot, Arjen P. 2016. 'Unstressed Vowels in Runic Frisian. The History of Frisian in the Light of the Germanic Auslautgesetze'. UW 65: 1-39.

Versloot, Arjen P. 2017a. 'Proto-Germanic ai in North and West Germanic'. Folia Linguistica 51: 281-324. 


\section{US WURK LXX (2021), p. 28}

Versloot, Arjen P. 2017b. 'The Riustring Old Frisian -ar Plurals: Borrowed or Inherited?'. In Laker and de Vaan (2017), 442-456.

Versloot, Arjen P. 2017c. 'Mith frethe to wasane "to be in peace": Remnants of the Instrumental Case in 13th- and 14th-Century Old Frisian'. Filologia Germanica-Germanic Philology 9: 201-230.

Versloot, Arjen P. 2021. 'Traces of a North Sea Germanic Idiom in the 5th-7th Centuries'. In John Hines and Nelleke IJssennagger (eds.). The Frisians. Abingdon: Routledge, 339-373.

von Richthofen, Karl. 1840a. Friesische Rechtsquellen. Berlin: Nicolai.

von Richthofen, Karl. 1840b. Altfriesisches Wörterbuch. Göttingen: Dieterich.

Vries, Oebele. 2001a. 'Die altfriesischen Urkunden'. In Munske et al. (2001), 594601.

Vries, Oebele. 2001b. 'Die Verdrängung des Altfriesischen als Schreibsprache'. In Munske et al. (2001), 606-613.

Vries, Oebele. 2006. 'Eine abwechslungsreiche Sprachlandschaft. Die Sprachen der nordöstlichen Niederlande mit Einschluss Ostfrieslands'. Niederdeutsches Wort 46: 5-26.

Vries, Oebele. 2012. De taal van recht en vrijheid. Studies over middeleeuws Friesland. Gorredijk: Bornmeer.

Vries, Oebele. 2015. 'Frisonica libertas: Frisian Freedom as an Instance of Medieval Liberty'. Journal of Medieval History 41: 229-248.

Yeandle, David. 2007. 'Early Christian Loans in Old Frisian: the Linguistic Evidence'. In Bremmer et al. (2007), 463-489. 